University of Nebraska - Lincoln

DigitalCommons@University of Nebraska - Lincoln

1985

\title{
The Diarrheal Response of Humans to Some Classic Serotypes of Enteropathogenic Escherichia coli is Dependent on a Plasmid Encoding an Enteroadhesiveness Factor
}

\author{
Myron M. Lavine \\ James P. Nataro \\ Helge Karch \\ Mary M. Baldini \\ James B. Kaper \\ See next page for additional authors
}

Follow this and additional works at: https://digitalcommons.unl.edu/usuhs

Part of the Medicine and Health Sciences Commons

Lavine, Myron M.; Nataro, James P.; Karch, Helge; Baldini, Mary M.; Kaper, James B.; Black, Robert E.; Clements, Mary Lou; and O'Brien, Alison D., "The Diarrheal Response of Humans to Some Classic Serotypes of Enteropathogenic Escherichia coli is Dependent on a Plasmid Encoding an Enteroadhesiveness Factor" (1985). Uniformed Services University of the Health Sciences. 119. https://digitalcommons.unl.edu/usuhs/119

This Article is brought to you for free and open access by the U.S. Department of Defense at DigitalCommons@University of Nebraska - Lincoln. It has been accepted for inclusion in Uniformed Services University of the Health Sciences by an authorized administrator of DigitalCommons@University of Nebraska Lincoln. 


\section{Authors}

Myron M. Lavine, James P. Nataro, Helge Karch, Mary M. Baldini, James B. Kaper, Robert E. Black, Mary Lou Clements, and Alison D. O'Brien 


\title{
The Diarrheal Response of Humans to Some Classic Serotypes of Enteropathogenic Escherichia coli is Dependent on a Plasmid Encoding an Enteroadhesiveness Factor
}

\author{
Myron M. Levine, James P. Nataro, \\ Helge Karch, Mary M. Baldini, \\ James B. Kaper, Robert E. Black, \\ Mary Lou Clements, and Alison D. O'Brien
}

\author{
From the Center for Vaccine Development, Division of \\ Geographic Medicine, University of Maryland \\ School of Medicine, Baltimore; the Department \\ of Microbiology, Uniformed Services University \\ of the Health Sciences, Bethesda, Maryland; and \\ the Institut fur Medizinische Mikrobiologie und \\ Immunologie, Universitats-Krankenhaus Eppendorf, \\ Arbeiten Krankenhaushygiene, Hamburg, \\ Federal Republic of Germany
}

\begin{abstract}
Isolates of the most common O serogroups of enteropathogenic Escherichia coli (EPEC) associated with infant diarrhea (designated class I) adhere to Hep- 2 cells; the genes for this adhesin, termed EPEC adherence factor (EAF), are located on plasmids 50-70 MDa in size. Volunteers ingested $10^{10}$ organisms of an 0127:H6 Hep-2-adhesive class I strain (E2348/69) or its plasmid-minus, nonadhesive derivative. Diarrhea occurred in nine of 10 volunteers who ingested the parent strain (mean, $1,178 \mathrm{ml}$ ) but in only two of nine who took the plasmid-minus variant (mean, $433 \mathrm{ml} ; P<.006$ ). All volunteers ill from strain E2348/69 mounted serum IgA and IgG responses to a 94-kDa plasmid-associated outer membrane protein of E2348/69; this protein was found in other class I EPEC but not in enterotoxigenic or meningitic strains. The 50-70-MDa EAF plasmid seems necessary for full expression of pathogenicity in EPEC that exhibit Hep-2 adhesiveness. EPEC isolates of certain other, less common, O serogroups $(\mathrm{O} 44, \mathrm{O} 86$, and $\mathrm{O114})$ are rarely Hep-2 adhesive. These EPEC, designated class II, possess distinct 50-70 MDa plasmids lacking EAF genes. Diarrhea was caused by $10^{8}$ or $10^{10}$ organisms of an O114:H2 class II EPEC strain (mean, $1,156 \mathrm{ml}$ ) in six of 11 volunteers. This result confirmed that class II EPEC are pathogenic by a mechanism not involving Hep-2 adhesiveness.
\end{abstract}

Enteropathogenic Escherichia coli (EPEC) refers to certain serotypes of $E$. coli that were first incriminated in epidemiological studies in the 1940s and 1950 s as causes of epidemic and sporadic infant diarrhea [1-5]. By the late 1950s, the standard technique for detecting these pathogens involved identifying them by agglutination with appropriate

Received for publication 22 October 1984, and in revised form 20 March 1985.

Informed consent was obtained from participants in this clinical research study, which followed the guidelines of the Department of Health and Human Services. The protocol was approved by the Human Volunteer Research Committee at the University of Maryland and the Clinical Review Sub-Panel of the National Institute of Allergy and Infectious Diseases.

This work was supported by research contracts NO1-AI-12666 from the National Institute of Allergy and Infectious Diseases and DAMD 17-83-C-3074 from the U. S. Army Medical Research and Development Command.

Please address requests for reprints to Dr. M. M. Levine, Center for Vaccine Development, University of Maryland School of Medicine, 10 South Pine Street, Baltimore, Maryland 21201. antisera [6-8]. Although no biochemical, microbiological or animal-model assays at that time could demonstrate an inherent pathogenicity vis-à-vis other $E$. coli, experimental challenge studies in the early 1950s in the United States, England, and Japan confirmed that strains of serogroups O55, O111, and O127, isolated from infants with gastroenteritis, caused diarrhea when fed to volunteers [9-14]. Also at this time, Ewing et al. $[6,8,15]$ in the United States and Taylor [7] in England noted that among all the EPEC, certain O serogroups, including O26, O55, O111, O119, O127, and O128, were particularly frequent and epidemiologically well-incriminated in association with diarrhea, whereas isolates of other EPEC O serogroups, such as O44, O86, and O114, were less common. Serogroup O142 had not yet been recognized as an EPEC at the time of those publications.

Interest in the pathogenesis of EPEC diarrhea was markedly renewed in 1978, when it was shown that EPEC strains of serogroups $\mathrm{O} 127$ and $\mathrm{O} 142$ caused a notable diarrheal illness in young adult volunteers 
[16], although these strains did not elaborate heatlabile (LT) or heat-stable (ST) enterotoxins and did not manifest shigella-like invasiveness for epithelial cells. These investigators concluded that EPEC cause diarrhea by other pathogenetic mechanisms. Shortly thereafter, Cravioto et al. [17] found that $80 \%$ of the EPEC strains that they examined adhered to Hep- 2 cells in tissue culture in the presence of Dmannose, a property found to be uncommon in other $E$. coli. Examination of the ultrastructure of EPEC infection in intestinal biopsies of ill infants $[18,19]$ and in animal models $[20,21]$ has revealed a distinct histopathologic lesion in which the EPEC intimately adhere to enterocytes, an occurrence resulting in dissolution of microvilli and cupping of the enterocyte outer membrane around the bacteria. So far, this lesion has been identified in infections due to EPEC of serogroups O26, O55, O111, O114, O119, O125, $\mathrm{O} 127$, and $\mathrm{O} 142$.

Baldini et al. [22] noted that 31 of 32 EPEC strains possessed a plasmid 50-70 MDa in size. Working with E2348/69, an O127:H6 strain that causes diarrhea in volunteers, these workers found that the genes encoding Hep- 2 adhesiveness and the ability to adhere to the intestinal mucosa of colostrum-deprived piglets are encoded on a 60-MDa plasmid. The term EPEC adherence factor (EAF) has been suggested to refer to the plasmid-mediated adhesin that confers Hep-2 adherence.

Nataro et al. [23, 24] and Baldini et al. [25] have isolated a one-kilobase pair $(\mathrm{Kb})$ fragment from the 60-MDa plasmid of E2348/69 that has proved to be a highly sensitive and specific DNA hybridization probe for detecting EPEC strains that exhibit Hep2 adhesiveness. In field studies in Peru with this DNA gene probe, these workers noted that Hep-2 adhesiveness was more frequently found among EPEC serogroups considered to be the most important causes of epidemic and sporadic EPEC diarrhea worldwide and that this trait correlated with the pathogenicity of these strains. In contrast, EPEC of the serogroups O44, O86, and O114, rarely found causing outbreaks and of generally lesser significance in sporadic diarrhea, were associated with diarrhea though they did not carry genes for EAF. In light of these observations, Nataro suggested the following designations: class I for serogroups O55, O111, O119, O127, O128, and O142; and class II for serogroups O44, O86, and O114.

Volunteer studies with representative class I and II EPEC strains were carried out to determine whether the 60-MDa plasmid of E2348/69 (O127:H6) affects pathogenicity and whether an O114:H2 class II EPEC is capable of causing diarrhea, although lacking the genes for Hep-2 adhesiveness.

\section{Subjects and Methods}

Bacterial strains. $E$. coli strain E2348/69 (O127:H6), isolated during an outbreak of infant diarrhea in Taunton, England [26], was provided by Bernard Rowe (Division of Enteric Pathogens, Central Public Health Laboratory, London). Strain E2348/69 possesses plasmids of 60 and $5 \mathrm{MDa}$ [22], adheres to and forms microcolonies on Hep- 2 cells [22], attaches to the intestinal mucosa of colostrumdeprived piglets [21], and hybridizes with a gene probe that detects Hep-2-adhesion genes [23, 24]. Strain MAR 20 is a derivative of E2348/69 cured of the 60-MDa plasmid, as described previously [22], that cannot adhere to Hep-2 cells or piglet intestinal mucosa and is probe negative. E. coli E128010 (O114:H2) was isolated from an infant with sporadic diarrhea in Bangladesh [27]. This strain possesses two plasmids, of 50 and $60 \mathrm{MDa}$, but does not adhere to Hep-2 cells and is probe negative. As previously reported, the above strains do not carry genes for ST or LT production, do not hemagglutinate human or bovine red blood cells, and are not invasive in the guinea pig keratoconjunctivitis test $[16,27$, 28]. Other pertinent microbiological and biologic properties of these strains are summarized in table 1 .

Strains E2348/69, MAR 20, and E128010 were examined for their ability to produce Shiga-like toxin by the HeLa-cell cytotoxicity method of O'Brien et al. [29]. Extracts of strains that were cytotoxic for $\mathrm{HeLa}$ cells were reacted with specific Shiga antitoxin to determine if the cytotoxicity could be neutralized.

Nine other $E$. coli strains were selected for examination of their outer membrane proteins. These included the following: enterotoxigenic $E$. coli strains $\mathrm{B}_{2} \mathrm{C}$ (O6:H16), H10407 (O78:H11), M424C1 (O6:H16), and B7A (O148:H28) [30, 31]; strains RS188 (O7:K1:H-) and RS408 (O75:K1), associated with neonatal meningitis and provided by Richard Silver (Bureau of Biologics, Bethesda, Md); EPEC strain E851/71 (O142:H6) [16]; and EPEC strains 0659/79 (O119:H6) and 2340/78 (O11la,b:H-), provided by I. Kaye Wachsmuth (Centers for Disease Control, Atlanta).

Volunteers and study design. Volunteers were 
Table 1. Biologic characteristics of three enteropathogenic strains of E. coli fed to healthy adult volunteers.

\begin{tabular}{|c|c|c|c|c|c|}
\hline Strain & Origin & Serotype & $\begin{array}{c}\text { Adhesion to Hep-2 cells } \\
\text { with microcolony formation }\end{array}$ & $\begin{array}{l}\text { Plasmids } \\
\text { (MDa) }\end{array}$ & $\begin{array}{l}\text { DNA hybridization } \\
\text { probe for Hep-2- } \\
\text { adhesive (EAF) genes }\end{array}$ \\
\hline E2348/69 & $\begin{array}{l}\text { Infant nursery diarrhea outbreak, } \\
\text { Taunton, England }\end{array}$ & O127:H6 & + & $\begin{array}{r}60 \\
5\end{array}$ & + \\
\hline MAR 20 & $\begin{array}{l}\text { Laboratory-derived, plasmid- } \\
\text { cured variant of E2348/69 }\end{array}$ & O127:H6 & - & 5 & - \\
\hline E128010 & $\begin{array}{l}\text { Sporadic infant diarrhea, } \\
\text { Bangladesh }\end{array}$ & $\mathrm{O} 114: \mathrm{H} 2$ & - & $\begin{array}{l}60 \\
50\end{array}$ & - \\
\hline
\end{tabular}

college students and other healthy adults aged 18-35 years from the Baltimore community; they were admitted to the 22-bed Isolation Ward of the Center for Vaccine Development for a period of 12 days. Methods of recruitment, medical screening, and clinical supervision have been previously described [16, 32]. The studies were explained in detail to the volunteers and signed, witnessed consent was obtained. In order to ensure the informed nature of consent, volunteers were required to pass a written examination containing multiple choice and true-false questions on all aspects of the study, including risks, benefits, procedures, and microbiology $[16,32]$.

In the first study, 19 volunteers were randomly chosen to receive $10^{10} \mathrm{E}$. coli strain E2348/69 or its plasmid-minus derivative, E. coli strain MAR 20. Neither the clinical observers nor the volunteers were aware of which strain they received.

In the second study, a total of 11 volunteers received $10^{8}$ or $10^{10} \mathrm{E}$. coli strain E128010. The inocula for bacterial challenge were prepared as previously described [16] and were fed to fasting volunteers with $2.0 \mathrm{~g} \mathrm{NaHCO}$ in $150 \mathrm{ml}$ of water.

The volunteers were closely observed for a period of $96 \mathrm{hr}$ after challenge, during which time all stools were collected, examined, graded, and cultured. Rectal swabs were obtained if a daily stool was not passed. Diarrhea was defined as two or more loose stools within $48 \mathrm{hr}$ totalling at least $200 \mathrm{ml}$ in volume or a single loose stool of $\geqslant 300 \mathrm{ml}$ in volume [32]. After $96 \mathrm{hr}$ of observation, all volunteers were given oral neomycin (500 mg every $6 \mathrm{hr}$ ) or colistimethate ( $300 \mathrm{mg}$ every $8 \mathrm{hr}$ ) for five days to eradicate the challenge strains.

Bacteriology. Stools and rectal swabs were cultured on Levine's eosin methylene blue (EMB) agar with and without nalidixic acid, $50 \mu \mathrm{g} / \mathrm{ml}$ (all challenge strains were nalidixic-acid resistant). Quantita- tive stool cultures were performed as previously described [16].

Probe hybridization. From stool cultures of volunteers who ingested E2348/69, lactose-positive colonies from the EMB plate containing nalidixic acid were agglutinated with $\mathrm{OK}$ antiserum prepared to E2348/69. After challenge, five agglutinating colonies per volunteer per day were saved to be tested with the DNA probe that detects the Hep-2-adherence genes. The colony hybridization technique of Moseley et al. [33] was followed with stringent conditions ( $50 \%$ formamide). In this way, the stability of the 60-MDa plasmid of E2348/69 in human intestinal infection was assessed.

Plasmid extraction. Plasmid extraction was performed by the rapid alkaline-extraction procedure of Birnboim and Doly [34], and plasmid profiles were visualized after electrophoresis through $0.7 \%$ agarose gels.

Serology. Sera collected before and 10, 21, and 28 days after challenge were examined for antibody to $\mathrm{O} 127$ or $\mathrm{O} 114 \mathrm{O}$ antigens by using the passive HA technique as previously described $[16,35]$. The $\mathrm{O} 127$ lipopolysaccharide was a phenol-water preparation (List Biologicals, Campbell, Calif) [36]. The O114 antigen was obtained by heat-alkaline treatment [37].

Outer membrane preparations. The $E$. coli strains were grown overnight in Pen Assay broth (Difco, Detroit) at $37 \mathrm{C}$, and outer membrane preparations (OMPs) were made by the method of Achtman et al. [38]. The protein content of the OMPs was measured by the technique of Markwell [39]. Samples of OMP (containing $30 \mu \mathrm{g}$ of protein) were electrophoresed in $11 \%$ polyacrylamide gel by the technique of Lugtenberg et al. [40] in the presence of SDS and the electrophorogram stained with coomassie blue.

Immunoblotting. Replicate 200- $\mu \mathrm{g}$ samples of 
E2348/69 OMP were subjected to SDS-PAGE. After electrophoresis, the proteins were transferred from polyacrylamide gel to nitrocellulose paper by vacuum blotting for $2 \mathrm{hr}$ by the procedure of Peferoen et al. [41], and the paper was cut into strips. The unabsorbed sites on the strips were blocked by incubation for $1 \mathrm{hr}$ at room temperature in PBS containing $0.5 \%$ polyoxylenesorbitan monolaurate (Tween-20; Fisher Chemical, Pittsburgh). The strips were then incubated overnight in $2 \mathrm{ml}$ of pre- (day 0 ) or postchallenge (day 28) human serum (challenged with E2348/69 or MAR 20) diluted 1:100 in PBS containing $0.5 \%$ Tween-20. The strips were washed three times ( $20 \mathrm{~min}$ each) in buffer before adding alkaline phosphatase-conjugated goat antibody to human IgA or antibody to IgG (Jackson Immunoresearch, Hamburg, FRG) for $2 \mathrm{hr}$ at room temperature. Following three 10-min washes in PBS/0.5\% Tween-20, the strips were exposed to 5-bromo-4-chloroindoxyl phosphate (Sigma, St. Louis) substrate in the presence of nitroblue tetrazolium (Sigma), according to the method of Blake et al. [42], for $10 \mathrm{~min}$ at $37 \mathrm{C}$ to develop a colorimetric reaction. In later experiments, OMPs of the other strains were submitted to PAGE, vacuum blotted onto nitrocellulose filters, reacted with day- 28 convalescent serum from a volunteer who developed diarrhea with strain E2348/69, and treated with conjugated antibody to IgA followed by substrate.

\section{Results}

Class I EPEC. Shiga toxin. Both strain E2348/69 and its plasmid-minus derivative MAR 20 produced trace amounts of a Shiga-like toxin that was neutralized by specific Shiga antitoxin. Trace amounts of Shiga-like toxin were defined as $\leqslant 200$ $50 \%$ HeLa-cell cytotoxic doses per mg of cell-lysate protein.

Clinical. Diarrhea occurred in nine $(90 \%)$ of 10 volunteers who received strain E2348/69 but in only two $(22 \%)$ of nine who ingested the plasmid-minus derivative, MAR $20(P<.006$; table 2$)$. The two ill volunteers who received the plasmid-minus derivative had milder diarrhea (mean stool volume, $433 \mathrm{ml}$ ) than did those who ingested the parent strain (mean stool volume, $1,178 \mathrm{ml}$ ). Most of the volunteers who ingested strain E2348/69 developed anorexia, malaise, and abdominal gurgling, whereas these symptoms were not seen in the two volunteers who developed mild diarrhea after ingestion of MAR 20.

Bacteriology. All volunteers became colonized by the organism they ingested, and the geometric mean level of fecal excretion was similar in both groups $\left(7.3 \times 10^{7} \mathrm{E} 2348 / \mathrm{g}\right.$ and $2.6 \times 10^{8} \mathrm{MAR}$ 20/g).

Isolates of E2348/69 from stool cultures of volunteers who ingested that strain were tested for the presence of the Hep-2-adhesive genes by means of a gene probe. Of 174 E2348/69 isolates tested, only 57 $\mathbf{3 3 \%}$ ) were positive with the probe. Sixty of the 174 isolates were randomly selected for plasmid analysis. All the probe-negative isolates also lacked the 60-MDa plasmid; in contrast, all probe-positive isolates possessed the plasmid. The proportion of plasmid-minus, Hep-2-negative isolates was similar on all postchallenge days.

The possibility that spontaneous curing of the plasmid occurred in the act of preparation of the challenge inoculum was examined by a reconstruction experiment, in which the inoculum-preparation procedure was repeated and the organisms probed

Table 2. Clinical response of volunteers after ingestion of an O127:H6 EPEC (class I) strain with and without its 60-MDa plasmid or of an O114:H2, class II EPEC.

\begin{tabular}{lcccc}
\hline Strain ingested & Dose & $\begin{array}{c}\text { Diarrhea } \\
\text { attack rate* }\end{array}$ & $\begin{array}{c}\text { Mean diarrheal } \\
\text { stool volume (range) }\end{array}$ & $\begin{array}{c}\text { Positive } \\
\text { stool cultures* }\end{array}$ \\
\hline E2348/69 (O127:H6, with plasmid) & $10^{10}$ & $9 / 10^{\dagger}$ & $1,178 \mathrm{ml}$ & $10 / 10$ \\
MAR 20 (O127:H6, without plasmid) & $10^{10}$ & $2 / 9 \dagger$ & $433 \mathrm{ml}$ & $9 / 9$ \\
E128010 (O114:H2) & $10^{8}$ & $3 / 6$ & $(269-596)$ \\
& $10^{10}$ & $3 / 5$ & $(328-2,045)$ & $1,225 \mathrm{ml}$ \\
& & & $(390-1,785)$ & $5 / 5$ \\
\hline
\end{tabular}

* No. positive/no. of volunteers challenged.

$\dagger P<.006$ by two-tailed Fisher's exact test. 


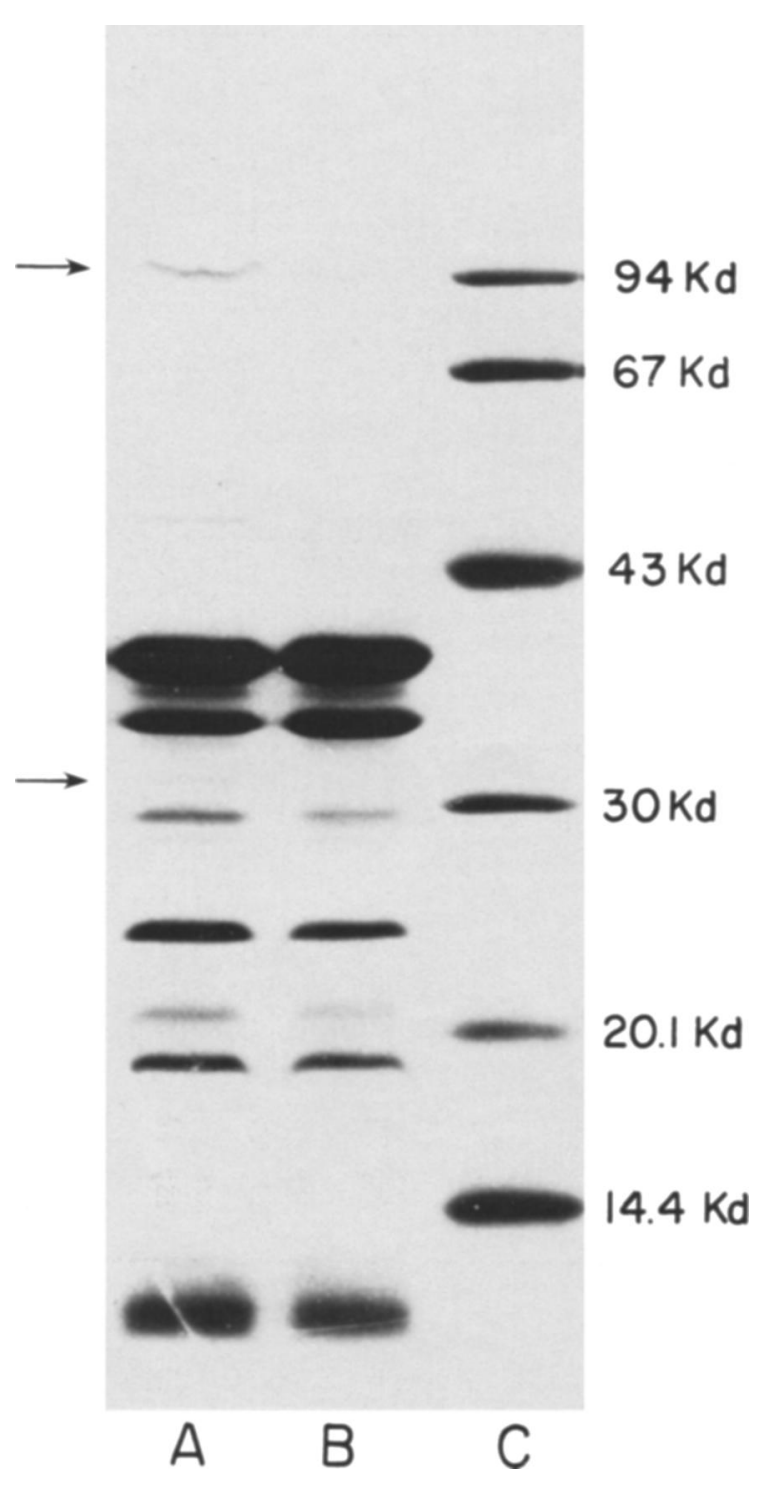

Figure 1. SDS-PAGE of outer membrane preparations (OMP) of $E$. coli strain E2348/69 (lane $A$ ) and its plasmid-minus derivative, MAR 20 (lane B). Molecular weight standards are in lane C (Low Molecular Weight Standards Kit; Pharmacia, Uppsala, Sweden). The upper arrow points to a prominent doublet protein band. The lower arrow points to a faint protein band.

after plating on Luria-agar (L-agar). The possibility that spontaneous cure occurred during the coproculture procedure was also examined by passing a fresh inoculum twice on EMB agar and twice on L-agar to mimic the clinical microbiological procedure and then performing the DNA hybridization. In both these instances, the prevalence of plasmidminus isolates of E2348/69 was $<1 \%$ of all colonies tested. Thus, the high prevalence $(67 \%)$ of plasmidminus colonies isolated from stool cultures of volunteers implies that plasmid curing occurred in vivo, in the human intestine.

Serology. The rate of seroconversion $(\geqslant$ fourfold rise) to 0127 antigen was similar in volunteers who ingested E2348/69 (eight of 10) and MAR 20 (eight of nine). The peak geometric mean titer after challenge among those who exhibited seroconversions was 49 in the E2348/69 recipients and 41 in those who ingested MAR 20.

Outer membrane profile. Analysis of the OMP of $E$. coli strains E2348/69 and MAR 20 (figure 1) reveals a $94-\mathrm{kDa}$ protein and a minor $31-\mathrm{kDa}$ protein that are absent in the plasmid-minus derivative, MAR 20.

Immunoblotting. Prechallenge (day 0 ) and postchallenge (day 28) sera from volunteers who ingested either $E$. coli strain E2348/69 or its plasmid-minus derivative MAR 20, were tested in an immunoblotting procedure for the presence of specific IgA and IgG antibodies to E2348/69 OMP antigens.

Results with the conjugated antibody to $\operatorname{IgA}$ shown in figure $2 \mathrm{~A}$ clearly demonstrate that volunteers challenged with the plasmid-containing parent strain, E2348/69, mounted a notable immune response to the $94-\mathrm{kDa}$ plasmid-associated protein. One of 10 recipients of strain E2348/69 (volunteer 4) had detectable antibody to this protein in the prechallenge specimen. In the convalescent (day 28) sera, however, all 10 recipients of E2348/69 showed antibody to the $94-\mathrm{KD}$ a protein, a result demonstrating that all nine seronegative volunteers seroconverted. It is of interest that the one volunteer who failed to develop diarrhea after ingestion of E2348/69 (table 2) was the individual in this group who had detectable antibody before challenge. One individual who ingested MAR 20 (volunteer 1, figure 2B) had detectable antibody in both pre- and postchallenge specimens; no volunteers in this group manifested seroconversions in antibody to the $94-\mathrm{kDa}$ protein. Identical results were obtained when levels of IgG antibody were measured with conjugated antibody to IgG (data not shown). An immune response to the $31-\mathrm{kDa}$ plasmid-encoded protein was not detected.

In figure 3, the day-28 serum of one E2348/69 volunteer who seroconverted is shown tested against E2348/69 OMP directly and after adsorption with MAR 20 or E2348/69 bacteria. The unadsorbed serum shows a strong antibody reaction to the $94-\mathrm{kDa}$ 
Figure 2. (Top) Immunoblot of sera of volunteers who ingested $E$. coli strain E2348/69 tested against strain E2348/ 69 OMP. The arrow points to the 94-kDa plasmid-associated protein. (Bottom) Immunoblot of sera of volunteers who ingested $E$. coli strain MAR 20 tested against strain E2348/69 OMP. The arrow points to the $94-\mathrm{kDa}$ plasmid-associated protein.
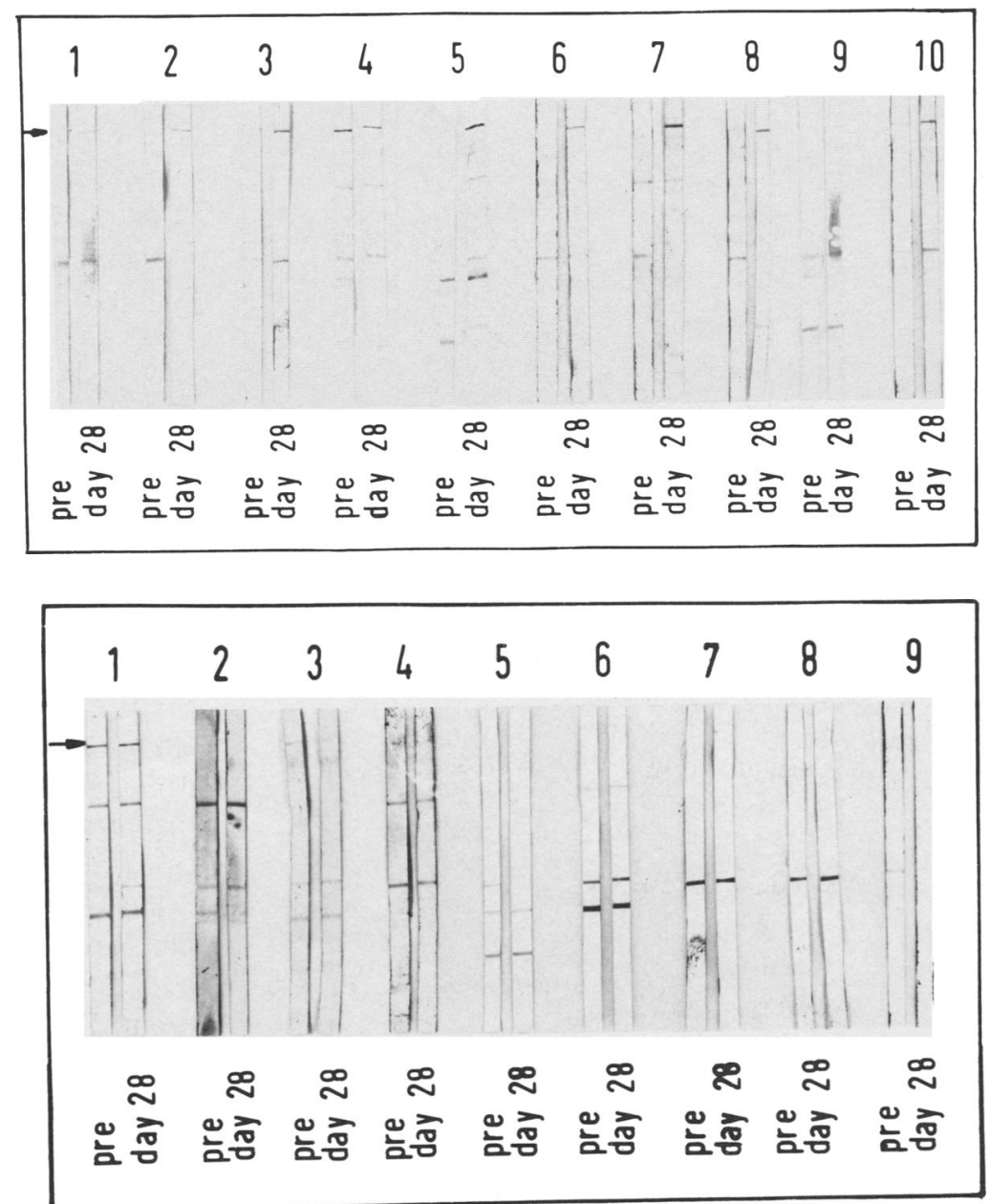

protein and evidence of lesser amounts of antibody combining with other proteins (figure 3, lane A). Adsorption with E2348/69 cells removes virtually all antibody (figure 3, lane B). In contrast, adsorption with MAR 20 removes antibody to the other OMP proteins but leaves antibody to the $94-\mathrm{kDa}$ protein (figure 3, lane C).

In view of the notable immune response demonstrated to the presumably plasmid-associated, 94$\mathrm{kDa}$ protein, OMPs of 10 other selected strains of $E$. coli were examined for the presence of the $94-\mathrm{kDa}$ protein in immunoblots by using day- 28 convalescent sera from a patient who ingested E2348/69 as an immunologic probe. Results are shown in table 3. The four enterotoxigenic $E$. coli and two meningitis strains lacked the $94-\mathrm{kDa}$ protein. In contrast, the O119, O111, and O142 EPEC strains, all of which are Hep-2 adhesive and positive with the DNA probe, possessed a protein of $\sim 94 \mathrm{kDa}$ that reacted with the convalescent antiserum. E. coli E128010, an O114 class II EPEC strain (see below) that is negative with the EAF gene probe and does not adhere to Hep-2 cells, was negative for the $94-\mathrm{kDa}$ protein.

Class II EPEC. The O114:H2 EPEC strain (E128010) that was fed to volunteers caused unequivocal diarrheal illness in 50\%-60\%. The clinical and bacteriologic results are summarized in table 2. Like strain E2348/69, E128010 was found to produce trace levels of Shiga-like toxin. Nine of 11 recipients of E128010 manifested serological rises in titer to the O114 antigen.

\section{Discussion}

Plasmids encode critical virulence properties for enterotoxigenic [43-45], enteroinvasive [46], and enterohemorrhagic [47] $E$. coli that cause diarrheal disease [27]. It is now obvious that the $50-70-\mathrm{MDa}$ 


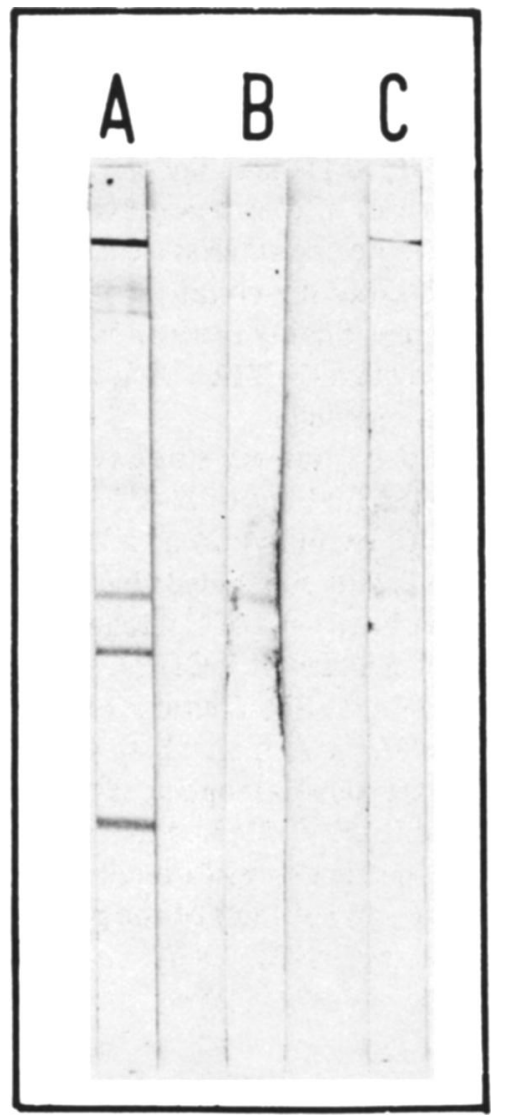

Figure 3. The day-28 postchallenge serum from a volunteer who ingested $E$. coli strain E2348/69 and seroconverted to the 94-kDa protein is shown tested against strain E2348/69 OMP. The serum was tested unadsorbed (lane $A$ ) and after adsorption with E2348/69 (lane B) or MAR 20 (lane $C$ ) bacteria.

plasmid that is present in class I EPEC also encodes genes that greatly affect the pathogenicity of such strains in humans. Both of the O127:H6 strains that were fed to volunteers had smooth lipopolysaccaride $\mathrm{O}$ antigens and elaborated similar levels of Shiga-like toxin. Fecal excretion was the same for both strains, as was the frequency and magnitude of the serum O-antibody response. However, the 60MDa plasmid apparently encodes or regulates an adhesin that is not expressed in the absence of the plasmid. OMPs of E2348/69 and MAR 20 were examined because the observations of Scotland et al. [48] suggest that nonfimbrial adhesins are involved in attachment of EPEC to Hep-2 cells. Our studies revealed a $94-\mathrm{kDa}$ outer membrane protein produced by E2348/69 but not by MAR 20, to which volunteers who ingested E2348/69 mounted an IgA and
IgG immune response in serum (figures 1-3). This 94-kDa protein was absent in four enterotoxigenic $E$. coli strains and in two strains from patients with neonatal meningitis. In contrast, three Hep-2-adhesive, EAF gene probe-positive EPEC strains of serogroups O111, O142, and O119 were found to possess the $94-\mathrm{kDa}$ outer membrane protein. These preliminary data suggest that this protein may play a role in the pathogenesis of diarrhea due to EPEC strains that cause localized adhesion on Hep-2 cells and are positive with the EAF gene probe. Studies are underway to investigate this association in a larger and more varied series of $E$. coli strains. It is of further interest that the one volunteer among the group of 10 who did not develop diarrhea when fed $E$. coli strain E2348/69 was the one individual in the group who, before challenge, had antibody to the $94 \mathrm{kDa}$

Table 3. Occurrence of a 94-kDa protein in outer membrane preparations of $E$. coli strains from various clinical sources, detected in immunoblots.

\begin{tabular}{|c|c|c|c|}
\hline $\begin{array}{l}\text { Class of } \\
E . \text { coli }\end{array}$ & Serotype & Source & $\begin{array}{l}\text { 94-kDa outer } \\
\text { membrane } \\
\text { protein de- } \\
\text { tected with } \\
\text { immunologic } \\
\text { probe }\end{array}$ \\
\hline \multicolumn{4}{|c|}{ Enterotoxigenic } \\
\hline $\mathrm{B}_{2} \mathrm{C}$ & O6:H16 & $\begin{array}{l}\text { travelers' } \\
\text { diarrhea }\end{array}$ & - \\
\hline H10407 & O78:H11 & $\begin{array}{l}\text { travelers' } \\
\text { diarrhea }\end{array}$ & - \\
\hline $\mathrm{M} 424 \mathrm{Cl}$ & O6:H16 & $\begin{array}{l}\text { travelers' } \\
\text { diarrhea }\end{array}$ & - \\
\hline B7A & O148:H28 & $\begin{array}{l}\text { travelers' } \\
\text { diarrhea }\end{array}$ & - \\
\hline \multicolumn{4}{|c|}{ K1 meningitic } \\
\hline RS188 & $\mathrm{O} 7: \mathrm{K} 1: \mathrm{H}-$ & $\begin{array}{l}\text { neonatal } \\
\text { meningitis }\end{array}$ & - \\
\hline RS408 & O75:K71 & $\begin{array}{l}\text { neonatal } \\
\text { meningitis }\end{array}$ & - \\
\hline \multicolumn{4}{|l|}{ EPEC } \\
\hline $0659 / 78$ & O119:H6* & $\begin{array}{l}\text { infant } \\
\quad \text { diarrhea }\end{array}$ & + \\
\hline $2430 / 78$ & O111a,b:H - * & $\begin{array}{l}\text { infant } \\
\quad \text { diarrhea }\end{array}$ & + \\
\hline E851/71 & O142:H6* & $\begin{array}{l}\text { infant } \\
\quad \text { diarrhea }\end{array}$ & $+\dagger$ \\
\hline E128010 & O114:H2 & $\begin{array}{l}\text { infant } \\
\quad \text { diarrhea }\end{array}$ & - \\
\hline
\end{tabular}

* Serotypes form microcolonies on Hep-2 cells and are positive with the EAF gene probe.

$\dagger$ The outer membrane protein that reacted with the immunologic probe was $96 \mathrm{kDa}$. 
protein. Although this observation involves only one patient, it should encourage further studies to assess the role of antibody to the $94-\mathrm{kDa}$ protein in mediating protection and to investigate the protein as a potentially important antigen in development of future vaccines against class I EPEC.

Because the Hep-2-adherence plasmid is moderately large, there are ample segments of cryptic DNA that conceivably could encode other, currently unrecognized, virulence factors. We are currently analyzing the protein products of plasmid derivatives that are specifically inactivated in the Hep-2-adherence genes. A future volunteer study with the O127:H6 strain, containing the inactivated Hep-2 genes will definitively elucidate the role of these genes.

A surprise finding was that although the EAF plasmid is extremely stable in vitro, considerable spontaneous cure was observed after intestinal passage. It should be noted that this plasmid loss occurred after infection of adults, a group not considered naturally at high risk for this pathogen, and was observed for only one strain [1]. Plasmid loss in the intestine of young infants may be much less frequent. These data may provide a clue to a better understanding of the epidemiology of EPEC. For example, when identified by serotyping, the difference in rate of isolation of EPEC from infants with diarrhea vs. healthy controls is highly significant in infants less than six months of age, whereas the rates of isolation are similar in infants more than six months of age $[1,49]$. On the basis of observations in the volunteer studies described herein, one would want in future epidemiological studies to ascertain whether the fecal isolates from class I EPEC from cases and controls of various ages possess EAF. It is conceivable that although the isolation of EAF-positive EPEC is high in very young infants with diarrhea, older children and healthy controls may more often be colonized with nonpathogenic, plasmid-minus variants, like our volunteers who were colonized with MAR 20. The observation of in vivo plasmid loss in volunteers also provides a note of caution to investigators examining EPEC strains from sporadic cases of diarrhea or from outbreaks. Multiple isolates from each individual must be examined before concluding that the implicated EPEC strain lacks the EAF plasmid. Epidemiological studies are underway to test these hypotheses.

Strain E128010, an O114:H2 class II EPEC that contains two large (50- and $60-\mathrm{MDa}$ ) plasmids but is Hep-2 negative and probe negative, nevertheless caused diarrhea of a severity equal to that in volunteers who ingested E2348/69 (table 3). This shows that EPEC strains of the serogroups recognized by Ewing et al. [6, 8, 15] and Taylor [7] as being lessimportant causes of diarrhea (in comparison with class I EPEC), are nevertheless clearly diarrheagenic pathogens. Studies are commencing to investigate whether the presumably distinct 50-70-MDa plasmids found in class II EPEC, such as E128010, play a role in pathogenicity.

Results of the volunteer studies corroborate the epidemiological findings of Nataro et al. [24] who, on the basis of examination of a large number of isolates from Peru, concluded that EAF is important for the pathogenicity of $O$ serogroups designated class I (which includes O55, O111, O119, O127, O128, and O142), and that EPEC strains of class II (which contains the less common O44, O86, and O114 serogroups) are also pathogenic, even though they typically lack EAF. It is hoped that the preliminary studies described herein will stimulate other investigators to undertake studies of the pathogenicity of class I and class II EPEC.

\section{References}

1. Levine MM, Edelman R. Enteropathogenic Escherichia coli of classic serotypes associated with infant diarrhea: epidemiology and pathogenesis. Epidemiol Rev 1984;6: $31-51$

2. Bray J. Isolation of antigenically homogeneous strains of Bact. coli neapolitanum from summer diarrhoea of infants. Journal of Pathology and Bacteriology 1945;57:239-47

$\rightarrow$ Giles C, Sangster G. An outbreak of infantile gastroenteritis in Aberdeen. J Hyg (Lond) 1948;46:1-9

$\rightarrow$ Taylor J, Powell BW, Wright J. Infantile diarrhoea and vomiting: a clinical and bacteriological investigation. $\mathrm{Br}$ Med J 1949;2:117-41

5. Kauffmann F, DuPont A. Escherichia strains from infantile epidemic gastroenteritis. Acta Pathologica et Microbiologica Scandinavica 1950;27:552-64

6. Ewing WH. Enteropathogenic Escherichia coli serotypes. Ann NY Acad Sci 1956;66:61-70

7. Taylor J. Host specificity and enteropathogenicity of Escherichia coli. J Appl Bacteriol 1961;24:316-25

8. Ewing WH. Isolation and identification of Escherichia coli serotypes associated with diarrheal diseases. Atlanta: US Department of Health, Education and Welfare, 1963

9. Neter E, Shumway CN. E. coli serotype D433: occurrence in intestinal and respiratory tracts, cultural characteristics, pathogenicity, sensitivity to antibiotics. Proc Soc Exp Biol Med 1950;75:504-7

10. Ferguson WW, June RC. Experiments on feeding adult volunteers with Escherichia coli 111, $\mathbf{B}_{\mathbf{4}}$, a coliform organism 
associated with infant diarrhea. American Journal of Hygiene 1952;55:155-69

11. June RC, Ferguson WW, Worfel MT. Experiments in feeding adult volunteers with Escherichia coli $55, \mathrm{~B}_{5}$, a coliform organism associated with infant diarrhea. American Journal of Hygiene 1953;57:222-36

12. Koya G, Kosakai N, Kono M, Mori M, Fusakawa Y. Observations on the multiplications of Escherichia coli O-111, $B_{4}$ in the intestinal tract of adult volunteers in feeding experiments: intubation study with Miller-Abbott's double lumen tube. Jpn J Med Sci Biol 1954;7:197-201

13. Kirby AC, Hall EG, Coackley W. Neonatal diarrhoea and vomiting: outbreaks in the same maternity unit. Lancet 1950;2:201-7

14. Wentworth FH, Brock DW, Stulberg CS, Page RH. Clinical, bacteriological and serological observations on two human volunteers following ingestion of Escherichia coli O127:B8. Proc Soc Exp Biol Med 1956;91:586-8

15. Ewing WH, Davis BR, Montague TS. Studies on the occurrence of Escherichia coli serotypes associated with diarrheal disease. Atlanta: US Department of Health, Education and Welfare, 1963

16. Levine MM, Bergquist EJ, Nalin DR, Waterman DH, Hornick RB, Young CR, Stoman S. Escherichia coli strains that cause diarrhoeae but do not produce heat-labile or heat-stable enterotoxins and are non-invasive. Lancet 1978;1:1119-22

17. Cravioto A, Gross RJ, Scotland SM, Rowe B. An adhesive factor found in strains of Escherichia coli belonging to the traditional infantile enteropathogenic serotypes. Current Microbiology 1979;3:95-9

18. Rothbaum R, McAdams AJ, Giannella R, Partin JC. A clinicopathologic study of enterocyte-adherent Escherichia coli: a cause of protracted diarrhea in infants. Gastroenterology 1982;83:441-54

19. Ulshen MH, Rollo JL. Pathogenesis of Escherichia coli gastroenteritis in man-another mechanism. N Engl J Med 1980;302:99-101

20. Polotsky YE, Dragunskaya EM, Seliverstova VG, Avdeeva TA, Chakhutinskaya MG, Kétyi I, Vertényi A, Ralovich B, Emódy L, Málovics I, Safonova NV, Snigirevskaya ES, Karyagina EI. Pathogenic effect of enterotoxigenic Escherichia coli and Escherichia coli causing infantile diarrhoea. Acta Microbiologica Academiae Scientiarum Hungaricae 1977;24:221-36

21. Moon HW, Whipp SC, Argenzio RA, Levine MM, Giannella RA. Attaching and effacing activities of rabbit and human enteropathogenic Escherichia coli in pig and rabbit intestines. Infect Immun 1983;41:1340-51

$\rightarrow$ Baldini MM, Kaper JB, Levine MM, Candy DCA, Moon HW. Plasmid-mediated adhesion in enteropathogenic Escherichia coli. J Pediatr Gastroenterol Nutr 1983;2:534-8

23. Nataro JP, Scaletsky ICA, Kaper JB, Levine MM, Trabulsi LR. Plasmid-mediated factors conferring diffuse and localized adherence of enteropathogenic Escherichia coli. Infect Immun, 1985;48:378-83

$\rightarrow$ Nataro JP, Baldini MM, Kaper JB, Black RE, Bravo N, Levine MM. Detection of an adherence factor of enteropathogenic Escherichia coli with a DNA probe. J Infect Dis 1985;152:560-5
25. Baldini MM, Nataro JP, Levine MM, Black RE, Clements ML. Characterization of a plasmid-mediating adhesion in enteropathogenic Escherichia coli [abstract no. B128]. In: Abstracts of the 84th annual meeting of the American Society for Microbiology. Washington, DC: American Society for Microbiology, 1984

26. Taylor J. Infectious infantile enteritis, yesterday and today. Proceedings of the Royal Society of Medicine 1970; 63:1297-1301

27. Levine MM, Kaper JB, Black RE, Clements, ML. New knowledge on pathogenesis of bacterial enteric infections as applied to vaccine development. Microbiol Rev 1983; 47:510-50

28. Robins-Browne RM, Levine MM, Rowe B, Gabriel EM. Failure to detect conventional enterotoxins in classical enteropathogenic (serotypes) Escherichia coli strains of proven pathogenicity. Infect Immun 1982;38:798-801

$\rightarrow$ O'Brien AD, LaVeck GD, Thompson MR, Formal SB. Production of Shigella dysenteriae type 1-like cytotoxin by Escherichia coli. J Infect Dis 1982;146:763-9

30. Levine MM, Rennels MB, Daya V, Hughes TP. Hemagglutination and colonization factors in enterotoxigenic and enteropathogenic Escherichia coli that cause diarrhea. J Infect Dis 1980;141:733-7

31. Levine MM, Ristaino P, Sack RB, Kaper JB, Ørskov F, Ørskov I. Colonization factor antigens I and II and type 1 somatic pili in enterotoxigenic Escherichia coli: relation to enterotoxin type. Infect Immun 1983;39:889-97

32. Levine MM, Black RE, Clements ML, Lanata C, Sears S, Honda T, Young CR, Finkelstein RA. Evaluation in humans of attenuated Vibrio cholerae El Tor Ogawa strain Texas Star-SR as a live oral vaccine. Infect Immun 1984;43:515-22

$\rightarrow$ Moseley SL, Huq I, Alim ARMA, So M, SamadpourMotalebi M, Falkow S. Detection of enterotoxigenic Escherichia coli by DNA colony hybridization. J Infect Dis 1980;142:892-8

34. Birnboim HC, Doly J. A rapid alkaline extraction procedure for screening recombinant plasmid DNA. Nucleic Acids Res 1979;7:1513-23

35. Levine MM, Nalin DR, Hoover DL, Bergquist EJ, Hornick RB, Young CR. Immunity to enterotoxigenic Escherichia coli. Infect Immun 1979;23:729-36

36. Westphal O, Jann K. Bacterial lipopolysaccharides: extraction with phenol-water and further applications of the procedure. In: Whistler RL, ed. Methods in carbohydrate chemistry. Vol. V. New York: Academic Press, 1965:83-91

37. Young VM, Sochard MR, Gillem HC. Infectious agents in infant diarrhea. I. A hemagglutination-inhibition procedure for detection of bacterial fractions in infant sera. Proc Soc Exp Biol Med 1960;105:635-8

38. Achtman M, Mercer A, Kusecek B, Pohl A, Heuzenroeder M, Aaronson W, Sutton A, Silver RP. Six widespread bacterial clones among Escherichia coli $\mathrm{K} 1$ isolates. Infect Immun 1983;39:315-35

39. Markwell MAK, Haas SM, Bieber LL, Tolbert N-E. A modification of the Lowry procedure to simplify protein determinations in membrane and lipoprotein samples. Anal Biochem 1978;87:206-10

40. Lugtenberg B, Meijers J, Peters R, van der Hoek P, van Al- 
phen L. Electrophoretic resolution of the "major outer membrane protein" of Escherichia coli K12 into four bands. FEBS Lett 1975;58:254-259

41. Peferoen M, Huybrechts R, De Loof A. Vacuum blotting: a new simple and efficient transfer of proteins from sodium dodecyl sulfate-polyacrylamide gels to nitrocellulose. FEBS Lett 1982;145:369-72

42. Blake MS, Johnston KH, Russel-Jones X, Gotschlich EC. A rapid, sensitive method for detection of alkaline phosphatase-conjugated anti-antibody on Western blots. Anal Biochem 1984;136:175-9

43. Skerman FJ, Formal SB, Falkow S. Plasmid-associated enterotoxin production in a strain of Escherichia coli isolated from humans. Infect Immun 1972;5:622-4

$\rightarrow$ Gyles C, So M, Falkow S. The enterotoxin plasmids of Escherichia coli. J Infect Dis 1974;130:40-9

45. Evans DG, Silver RP, Evans DJ Jr, Chase DG, Gorbach SL. Plasmid-controlled colonization factor associated with vir- ulence in Escherichia coli enterotoxigenic for humans. Infect Immun 1975;12:656-67

46. Harris JR, Wachsmuth IK, Davis BR, Cohen ML. Highmolecular-weight plasmid correlates with Escherichia coli enteroinvasiveness. Infect Immun 1982;37:1295-8

47. Wells JG, Davis BR, Wachsmuth IK, Riley LW, Remis RS, Sokolow R, Morris GK. Laboratory investigation of hemorrhagic colitis outbreaks associated with a rare Escherichia coli serotype. J Clin Microbiol 1983;18:512-20

48. Scotland SM, Richmond JE, Rowe B. Adhesion of enteropathogenic strains of Escherichia coli (EPEC) to HEp-2 cells is not dependent on the presence of fimbriae. FEMS Lett 1983;20:191-5

49. Toledo M RF, Alvariza M do CB, Murahovschi J, Ramos SRTS, Trabulsi LR. Enteropathogenic Escherichia coli serotypes and endemic diarrhea in infants. Infect Immun 1983;39:586-9 